\title{
Entrepreneurial self-efficacy development: an effective intervention for sustainable student entrepreneurial intentions
}

\section{Olusegun Matthew Awotunde and Thea van der Westhuizen*}

College of Law and Management Studies, School of Management, IT and Governance, University of KwaZulu-Natal, Durban, 4001, South Africa ORCID: https//orcid.org/0000-0002-0362-2847

ORCID: https://orcid.org/0000-0001-8795-4023

Email: 217080901@stu.ukzn.ac.za

Email: vanderwesthuizent@ukzn.ac.za

${ }^{*}$ Corresponding author

\begin{abstract}
Eco-systemic disconnect in youth entrepreneurs' support systems is a challenge in most developing countries and adversely affects the success of entrepreneurship education. The study investigated the extent to which the application of systemic action learning and action research (SALAR) affects students' entrepreneurial self-efficacy (ESE) and determined relationships between ESE development, entrepreneurial intention and action. A quantitative design was used with a structured, self-administered, 7-point Likert scale survey through a test-retest method, over nine months amongst university students at a selected university in South-Africa. A purposive (non-probability) sampling technique was adopted for the administration of 230 questionnaires. Inferential statistics were used to examine the relationship between the constructs. Findings indicated a significant relationship between the application of SALAR and students' ESE development, intention and action. The findings propose a flexible social technology model (SHAPE) and methodology (SALAR) that other higher education institutions can adapt to facilitate youth entrepreneurship education development.
\end{abstract}

Keywords: entrepreneurship education; action learning; action research; SHAPE; shifting hope activating potential entrepreneurship; entrepreneurial self-efficacy; entrepreneurial intention; entrepreneurial action; entrepreneurial mindset; entrepreneurial eco-systems.

Reference to this paper should be made as follows: Awotunde, O.M. and van der Westhuizen, T. (2021) 'Entrepreneurial self-efficacy development: an effective intervention for sustainable student entrepreneurial intentions', Int. J. Innovation and Sustainable Development, Vol. 15, No. 4, pp.475-495.

Biographical notes: Olusegun Matthew Awotunde is a $\mathrm{PhD}$ candidate at the University of KwaZulu-Natal, South Africa. He is a team member of the SHAPE research lab. His research focus includes human capital and youth entrepreneurship development through action learning. 
Thea van der Westhuizen ( $\mathrm{PhD}$; CPRP) is the academic leader of the Management and Entrepreneurship discipline at the University of KwaZulu-Natal. She is the chairperson of Entrepreneurship Development in Higher Education (EDHE)'s community of practice for entrepreneurship learning and teaching. Her entrepreneurial and academic projects received multiple awards, both locally and internationally. Being an entrepreneur, she was the founding director of the Garden Route Tourism Academy, Tesen Tourism Planning and Paddle for the Planet. As a scientist, she founded SHAPE (Shifting Hope Activating Potential Entrepreneurship), a social technology for systemic action learning and action research. She has over 20 years of teaching experience, working in several countries.

\section{Introduction}

Entrepreneurship is recognised as a viable solution to socioeconomic problems in which education is regarded as a driving factor to develop entrepreneurship culture and behaviour. It is problematic to view entrepreneurship as a save-all solution to socioeconomic development, as the sustainability of entrepreneurial actions requires a deep transformation of mindset within individuals (Van der Westhuizen, 2018). One of the expected sustainable outcomes of entrepreneurship education is the development and growth of the eco-system to facilitate graduates' self-reliance, entrepreneurial mindset, the introduction of new production systems, products and marketing through creativity, innovation and venture creation that will boost socioeconomic development (Kasemsap, 2016; Ndou et al., 2018).

This study introduced a novel approach to entrepreneurial education through a paradigm shift from theoretical or abstract teaching in the classroom to systemic action learning action research (SALAR) training, through creating, developing and facilitating an eco-system to support student entrepreneurial mindset development. This was intended to develop the entrepreneurship self-efficacy required for entrepreneurship intention and subsequent action, sustaining business ventures and improving their prospects as well as measurable societal value. This is complex to achieve in a society that believes that starting a business attracts instant wealth, where wealth is associated with only economic activities (Marais, 2013). Social wealth lies within deeper socioeconomic transformation.

Various factors were considered for shaping entrepreneurship education sustainability globally. In South Africa, societal attitude and perception play a pivotal role in the ecosystem and a national entrepreneurship culture that has a direct influence on the extent to which entrepreneurship activities are supported. The implication of this is that $48 \%$, $69.6 \%$ and $78.85 \%$ in 2003, 2014 and 2019 respectively of the adult population in South Africa demonstrated a positive attitude towards entrepreneurship as a career choice (Bowmaker-Falconer and Herrington, 2019/2020). The positive increase in the youth and nascent entrepreneurship action from 2017 to $2019(69.6 \%$ to $78.8 \%$ ) was as a result of the information technology, digital jobs and media (television, radio and social media) support for entrepreneurship as an acceptable career alternative to searching for a job (National Youth Enterprise Strategy, 2010; The Rockefeller Foundation, 2020). There was a notable increase in total early-stage entrepreneurial activity (TEA) in South Africa from 2016 through 2017 but the momentum was short-lived and in 2019 there was little 
or no increase in the TEA. There was no real development in 2017 at only $10.8 \%$, which was below the average of $12.1 \%$ (Bowmaker-Falconer and Herrington, 2020). These findings suggest that youth require the twenty-first-century skills that are regarded as essential to participate and contribute to the knowledge economy and its sustainability in developing African countries. The lack of such skills has resulted in the low level of total entrepreneurial activity that is reflected in South Africa's unemployment rate, which rose from $26.5 \%$ in the first quarter of 2016 to $27.7 \%$ in 2017 and $29 \%$ in 2019 (Statistics South Africa, 2019). To sustain the increase in entrepreneurial action among youth in South Africa requires that the development of skills be prioritised in higher education institutions to promote self-reliance during and after students' studies. This study supports Jones and Mullers' views that the development of entrepreneurial self-efficacy (ESE) is necessary for the fourth industrial revolution and economic development to be successful in South Africa (Jones and Muller, 2016).

The recurring global agenda on sustainable development since the 1970s, concomitant with the emergence of the fourth industrial revolution, has illustrated that change is inevitable. Entrepreneurship education from a sustainable development perspective is recognised as a driver that can change the prevailing paradigms regarding economic development and education in developing nations (Strachan, 2018). The developed world is continuously evolving and underdeveloped countries must also be ready to address the youth unemployment situation that requires urgent attention for socioeconomic sustainability (Comaroff and Comaroff, 2012). While global education systems focus on entrepreneurship for sustainable development and how it will develop innovation and creativity in learners for present and future work scenarios, the "shifting hope activating potential entrepreneurs" (SHAPE), a social technology for youth entrepreneurial development as proposed by Van der Westhuizen (2016), focuses on entrepreneurship education, training and development in line with the European Union's Entrepreneurship 2020 Action Plan (European Commission, 2013). This demands radical changes in all aspects of life to support the United Nations' Sustainable Development Goals (UNSDGs). To align this initiative, the South African Government launched the National Development Plan (Vision 2030) with a focus on providing an equitable and defined standard of living for all its citizens by 2030 (Fourie, 2018). This supports the United Nations' Sustainable Development Goals numbers four and one, namely increasing the availability of high-quality education and poverty eradication. For this proposal to become a reality, it needs to be implemented over the fifteen years of its establishment (National Planning Commission, 2013). To change the narratives of the economic challenges and systems' disconnect, human capital development needs to be holistically revisited through the education sector by developing the youth and students' entrepreneurship self-efficacy to ensure that they contribute to growing the economy.

Scholars believe that the best way to achieve the desired outcomes is through entrepreneurship education and training that will enhance entrepreneurship self-efficacy from young children's primary education through to their higher education to enable them to become sustainable entrepreneurs that can build bridges between environmental and social progress and market success (Morselli, 2019). This will address the prevailing systemic disconnect, as the SDGs are an interdependent framework that aspire to achieve world peace and security (Sachs et al., 2019).

This is a challenge in most African countries due to the deficiencies associated with their education systems (Sisk, 2017). Although South Africa is known for its training and development programs, these have not developed individual youth's self-sufficiency or 
developed their efficacy (Herrington and Kew, 2016; Shay and Wood, 2004). Entrepreneurship-oriented education and training are considered to be the precursors of entrepreneurial intention and action among post- and undergraduate students (Kubberød and Pettersen, 2017; Tfwala, 2018).

Entrepreneurship education and training are utilised to address the challenges created by an inadequate education system, academic inefficiency, inappropriate curricula and students' lack of entrepreneurship skills and self-efficacy (Nowiński et al., 2019; Mutanda et al., 2018). The majority of South Africans between the ages of 24 and 35 are ill-equipped to act innovatively or entrepreneurially to establish business ventures (Steenkamp, 2013; Littlewood and Holt, 2015; Herrington and Kew, 2016). To develop entrepreneurship knowledge and understanding, both in theory and practice, researchers need more understanding of the training concept and different methods of educating learners. This statement implies that the focus should be on the entrepreneurial mindset for the exhibition of entrepreneurial skills and action. The question is, to what extent can ESE be influenced by any targeted entrepreneurship education, training or intervention? This study focused on the ESE school of thought that entrepreneurship education develops and strengthens youth ESE with key skills, competencies, concepts and mental awareness of development (Pihie and Bagheri, 2010).

Government policies that reinforce such a culture (Moalusi, 2016) could impede the development of ESE (Villa-Vicencio, 2015). The South African Government has adopted a variety of measures to promote entrepreneurship, including incentives, grants and levies. Bitzer and Bijman (2015) noted that it is essential to determine if such initiatives promote innovation. The country's economy has been criticised for creating a reactive business environment rather than an innovative and proactive environment (Juma, 2015) such as those of Sweden, Germany, Luxembourg and Austria. This shortcoming has led to a high level of unemployment, poverty and inequality due to the exit of entrepreneurs from business as a result of low profit margins, inability to access funding and a lack of working capital (Bowmaker-Falconer and Herrington, 2020).

Given that entrepreneurship is widely regarded as a driver of economic empowerment, job creation and economic growth (Audretsch, 2007), the youth need to develop their entrepreneurial self-efficacy to become skilled, innovative and creative in preparation for entrepreneurship action. This highlights the need to promote an entrepreneurial mindset, not only amongst the youth but also amongst older people whose pensions may be inadequate to sustain them (Oseifuah, 2010). 'SHAPE' demonstrated the development method by incorporating systemic action learning and action research (SALAR) to drive youth entrepreneurship self-efficacy to act on their intentions (Van der Westhuizen, 2017).

Concerns have been expressed regarding graduates' low level of entrepreneurial orientation and lack of self-esteem (Matchaba-Hove and Goliath, 2016). Schachtebeck (2018) posits that these challenges are attributed to the teaching and learning methods adopted. In a similar study, Clegorne and Mitchell (2013) found that higher education institutions' teaching methods, courses and assessment tools are teacher-centred. Dhliwayo (2008) and Schachtebeck (2018) noted that teaching styles that stimulate students, supported by empirical learning and creative problem-solving are lacking in certain university courses. Necessity-driven potential entrepreneurs were let down because of the lack of business operating systems and life skills (Meyer and Synodinos, 2019). The widening skills gap adversely affects South Africans (Herrington et al., 2016). The government was requested to prioritise higher education and its sustainability to 
address such shortcomings (Ndayi, 2014). Efforts need to be channelled to entrepreneurship capacity building at all levels of government (Herrington et al., 2010). The foregoing discussion explains that the curricula, teaching and learning methods have not adequately developed the efficacy among youths' that is required in the twenty-first century (Mutanda et al., 2018). This is consistent with Holly's (2012) observation that the education system has failed to provide the youth with an appropriate entrepreneurial mindset and skills to engage in entrepreneurship at the basic level. This is regarded as the factor that most adversely affects entrepreneurship development in terms of education and training. This study examined the systemic disconnect amongst government agencies through SALAR. This study also explored ESE as a driver of youth entrepreneurial development using SALAR with the SHAPE social technology model. It also examined the need for collaboration in entrepreneurship education, training and development for newventure creation.

\subsection{Aim of the study}

The study aimed to examine if SHAPE social technology, through applying SALAR, developed students' entrepreneurial self-efficacy and the relevant competencies for intention and action. The objectives and hypotheses hereunder were formulated to investigate the research aim.

\subsection{Research objectives}

1 To examine the effects of entrepreneurship self-efficacy development on university students' entrepreneurship intention and action.

2 To determine if there is a relationship between the entrepreneurial self-efficacy constructs and entrepreneurship intention and action.

H1: There is a relationship between entrepreneurship self-efficacy development and individual entrepreneurship intention and action.

H2: There is a relationship between the entrepreneurship self-efficacy constructs and entrepreneurship intention and action.

\section{Literature review}

Entrepreneurial self-efficacy (ESE) is a factor for individual entrepreneurial development with different personal attributes that translate into entrepreneurial intention and action (Krecar and Coric, 2013). Scholars (Zhao et al., 2005; Barbosa et al., 2007) view ESE as a germane antecedent to entrepreneurial action or new venture creation. It should be regarded as an intrinsic process that takes into account the psychological makeup of the entrepreneur. This section defines entrepreneurship and entrepreneurial efficacy. The study employed SHAPE social technology and theory $U$ as it promotes transformation and enables ideas to be fulfilled (Van der Westhuizen, 2016, 2021). It does so by identifying a gap or opportunity in the immediate environment and promoting transformation to make decisions about desired future processes (Arawaana, 2010). Its constructs measure individuals' belief in their ability to accomplish a given task or launch 
a venture. It is considered to be a strong predictor of entrepreneurial intention and action (Boyd and Vozikis, 1994).

\subsection{Entrepreneurship}

Entrepreneurship refers to the act of an entrepreneur putting his/her principles into practice, while an entrepreneur is someone who applies business acumen, finance and innovation to produce an economic good (Shane and Venkataraman, 2000). Business acumen can be described as the appropriate understanding of how a business achieves its goals. Joseph Schumpeter cited in Fritsch (2017) defined entrepreneurship as innovation. An entrepreneur is seen as a person who is willing to convert a new idea or invention into a successful innovation (Binnui and Cowling, 2016). Entrepreneurship can be innovative in a variety of ways, including introducing a new product to the market or employing a new production method. It could also involve the ability to create a new market, discover a new source of raw materials or the establishment of a new organisation (Nunes, 2016). Numerous factors can influence a person to become an entrepreneur, including individual qualities, traits and behaviours, the environment, background, experience and disposition (Arenius and Minniti, 2005). The Reciprocal Causation Model (Dahling et al., 2013) explains the interdependence among the environment, personal factors and behaviour.

\subsection{Self-efficacy}

The origin of the concept of self-efficacy lies in Albert Bandura's social cognitive theory, which examines learning from a social experiential perspective (Tsai et al., 2016). It has been a key feature of numerous psychological theories, including those that relate to motivation, thought patterns, cognitive processes, decisions, future orientation and everyday behaviour (Tian et al., 2016). Concurrently, as an individual is performing, the mind is learning, thinking and experiencing; self-efficacy is therefore a cognitive mechanism for the stress reaction that the body experiences when performing the task at hand (Cappara et al., 2013). Self-efficacy develops based on past experiences of mastery (Butz and Usher, 2015). It measures individual competence within a specific framework, focusing on the individual's assessment of his or her ability to perform a specific task concerning the goals and standards rather than in comparison with the capabilities of others (Morris and Lummis, 2014). Someone with high self-efficacy typically seeks challenges and can tolerate failure, as he or she has a learning orientation (Lent et al., 2017).

\subsection{Entrepreneurial self-efficacy}

Entrepreneurial self-efficacy evaluates individuals' belief in their strength to act entrepreneurially. It refers to the individual's assessment of his or her capability to achieve success and meet challenging goals during the business start-up process (Williams and Rhodes, 2016). The definition entails cognition; the mental actions or processes of acquiring knowledge (Piperopoulos and Dimov, 2015). It also considers understanding thought, experience and the senses (Baronov, 2015). Self-efficacy for business start-up or growth is significant, as it emphasises the need for efficacy as a precursor to entrepreneurial intent (Ceresia and Mendola, 2019). Self-efficacy enables a person to focus on specific tasks and goals; the valence of the goals is considered in terms of whether they are positive or negative control beliefs (Cardon and Kirk, 2015). 
Expectancy theory is applied to define valence, which holds that people are encouraged to behave in a certain way because of the expected result (Huang, 2016). The result can be a negative or positive psychological valence (Ghoddousi et al., 2014) value assigned by one person to another or to an event, job, goal or the like basedon its attractiveness to the individual (Purvis et al., 2015). A substantial body of evidence exists to indicate that selfefficacy is a significant attribute of an entrepreneur and this can significantly affect business start-up and growth (Miao et al., 2016). Barbosa, Gerhardt and Kickul (2007) drew on the work of De Noble et al. (1999) and Chen et al. (1998) to develop the definition of ESE that was adopted for this study. They identified the four constructs of ESE described in the ensuing section.

Opportunity identification self-efficacy (OI_SE). Opportunity identification self-efficacy could be regarded as an individual's propensity or ability to scan the economy to identify a gap or opportunity to develop a product and market it to fulfil one's own needs and those of society or stakeholders in the venture (Drnovsek et al., 2010; Mamabolo et al., 2017). It is worth noting that opportunities in entrepreneurship are made, not found and creativity is needed to satisfy a particular market need. Scharmer and Kaufer (2013) found that in the reactive stages of Theory $U$, the learner co-initiates their idea through practice for the expected future to emerge. In terms of entrepreneurship, evaluation of the recognised opportunity, if developed, can lead to recognition of additional opportunities that represent added value through growth, development and expansion of the business (Van der Westhuizen, 2021). Unlike managers, entrepreneurs are adept at perceiving and exploiting opportunities before they are recognised by others (Hisrich and Peters, 1998). Consistent with this understanding, Wood and Bandura (1989) explained that direct experience is the best way to transform knowledge into skills, as one understands the positive and negative consequences of the action. A number of scholars found that learning experience such as training, an internship, action learning action research and practice have positive effects on ESE (Zhao et al., 2005; Liñán, 2005; Nyamuda and Van der Westhuizen, 2018). Olokundun et al. (2017) observed that experiential learning promotes a shared construct of ESE among higher education students. Through learning by doing, action learning and management simulations enhance students' skills (Van der Westhuizen and Goyayi, 2020).

Relationship Self-efficacy (REL_SE). This relates to a perception of possessing the charisma and ability to build successful relationships. Essential relationships include those with entrepreneurship enablers, potential investors and those who support the wellbeing, acceptability and sustainability of the venture. Van der Westhuizen (2021) refers to this as the meeting of like-minded and like-hearted business partners who share the same vision for venture creation and sustainability. At this stage, individuals establish relationships with stakeholders that will enable their dream to become a reality. It is also a planning stage for resources such as the factors of production, which include capital, labour, customers and suppliers without whose involvement the goals may not be achieved (Mueller and Goic, 2003). Scharmer (2007) refers to this (co-sensing) as when like-minded people cometogether to sense, agree and plan for the future.

Managerial self-efficacy ( $\left.M N G \_S E\right)$. This refers to the individual's perception of his or her ability to control, lead and impose authority to manage day-to-day activities during turbulent times or while experiencing failure. The manager should be capable of strategic thinking to identify solutions to business challenges that threaten the growth and 
sustainability of the enterprise (Mueller and Goic,2003). Managerial self-efficacy enables the entrepreneur to design job specifications for the efficient management of employees, equipment, finances and stakeholders. Providing assurance of the availability of employment and its specifications to all employees at all times for the growth of the firm and ensuring work-life balance strategies for optimal organisational performance.

Tolerance self-efficacy (TOL_SE). Bandura (1986) defined self-efficacy as a person's consideration of his or her ability to accomplish a certain level of performance. This should include the ability to take calculated risks and to appreciate failure, as this promotes innovation and new product development (Kapepa and Van Vuuren, 2019). Self-efficacy relates to individuals' perceptions and abilities to persevere and to work with limited supervision in times of challenge or change (such as economic recession) and in the face of challenges from competitors, stakeholders or internal parties. Embracing failure to ensure success is germane to venture sustainability and expansion. Tolerance self-efficacy in action learning is the key to entrepreneurial intention and action and the pillar upon which sustainable growth and development rest.

These dimensions of ESE were used to develop a new idea to promote nascent entrepreneurship amongst university students. This study adopted Theory U's five stages of social transformation technology to harness the potential of the student participants by applying systemic action learning action research in a training project with the acronym SHAPE (Shifting Hope Activating Potential Entrepreneurs) at the University of KwaZulu-Natal (UKZN), South Africa. Theory U was combined with the training project to enable the participants to overcome the challenges of insufficient knowledge and skills to identify gaps, innovate and create a suitable venture to reduce unemployment by developing their ESE using a social transformational technology pedagogy.

\section{Systemic action learning and action research}

SALAR was introduced as an intervention to facilitate entrepreneurship development training in a South African institution of higher learning context to connect entrepreneurship stakeholders within a learning space to develop youth entrepreneurs. It is an interactive process amongst the learners, their intermediaries and researchers to collectively co-create solutions to the eco-systemic disconnect and the challenges that nascent entrepreneurs encounter (Van der Westhuizen, 2016). It provides an avenue for the exchange of ideas to create initiatives and engage in dialogue, which allows researchers and practitioners to observe and to act upon the dynamics at the systemic level (Schweikert et al., 2013). It can be referred to as an activity or interaction among the stakeholders with the learning process, building students' self-efficacy and activating individual entrepreneurial orientation towards acting on intention.

\section{Entrepreneurship intention}

Thompson (2009) describes entrepreneurship intention as a "...self- acknowledged conviction by a person that intends to set up a new business venture and consciously plan to do so at some point in the future". A process of developing entrepreneurship potential 
for possible action in the future, which is an encouragement for entrepreneurial activity. The essence is to understand the dynamics of entrepreneurship. This occupies a pivotal role in start-up business decisions(Devonish et al., 2010). It is an evaluation of the efforts expended to perform the behaviour and as a general rule, the stronger the intention to engage in a behaviour the more successful the performance (Ajzen, 2011). This study intended to provide further impetus for entrepreneurship intention through SALAR for a sustainable solution to promoting entrepreneurial activity.

\section{Entrepreneurial action}

Entrepreneurial action follows an individuals' aspiration and vision that motivates them to become independent entrepreneurs (Van der Westhuizen, 2016). It can also be described as various qualities in an individual that compel him or her to pursue the desire to act entrepreneurially. The success of such actions as change makers does not depend on what one does or how it is done but on the inner place from which one operates (Scharmer and Kaufer, 2013). Entrepreneurship action is focused on three dimensions the process of finding creative or innovative solutions to societal needs, taking a calculated risk of venturing into the unknown and proactively pursuing entrepreneurial activities and opportunities to completion.

\section{Research method}

A descriptive, single-sample, longitudinal approach was adopted for this study. Due to the nature of the social technology employed for the study (SALAR), registered students of UKZN were invited to voluntarily participate in the study through an advertisement posted on the University of KwaZulu-Natal's notice system. The volunteers participated in a 13-week project entitled SHAPE 2017 with a focus on entrepreneurship students. Two hundred and thirty registered students volunteered to participate in the SHAPE training project as the main criterion for participation. The most consistent participants' data were collected objectively, analysed and interpreted through SPSS version 26 to confirm and evaluate their progressive behavioural changes and their entrepreneurial development. First-year honours and post-graduate students were selected because they had undergone theoretical learning and had prior knowledge of what entrepreneurship is in theory and were deemed ready to self-develop entrepreneurially. Research has shown that self-selected samples provide more transparent and complete responses than those who are selected by other means (Gosling et al., 2004). Barbosa's (2007) instruments were adapted to measure students' progressive ESE development and to build on the South African context measurement created by Van der Westhuizen (2016). The Opportunity Identification ESE (OI_ESE, 7 measurements), Relationship ESE (REL_ESE, 6 measurements), Managerial ESE (MNG_ESE, 11 measurements) and Tolerance ESE (TOL_ESE, 13 measurements) were construct indicators that were based on a 7-point Likert scale; while the rounds indicated the interval of time. The instruments were administered to the participants in the beginning, during and after the training project to examine their progressive development with regard to their entrepreneurial behaviour. 
The study employed purposeful sampling where 230 participants voluntarily registered and participated to develop their potential in an entrepreneurship development training project. A self-administered questionnaire was employed to collect primary data from the sample (Sekaran and Bougie, 2016). Standard ethical procedures were followed to examine the instrument for the study and a pilot study was conducted before the final data were collected in three rounds (before, during and after the training). The data analysis was based on 60 consistent participants from the initial 230 registered volunteers that participated in all the sessions of the SHAPE training project. This was to validate the aim of the study to examine whether or not SHAPE social technology, applying systemic action learning action research, developed students' ESE and competencies progressively for intention and action. This enabled the researcher to observe the progressive transformation and behavioural changes of the participants at intervals (Sekaran and Bougie, 2016).

This method was deemed suitable because of the nature of the study (SALAR), which was to examine the effects of ESE development on the participants at intervals and to elicit information from the participants who were prone to remain unemployed. Figure 1 indicates the SHAPE weekly training model and the participants' progressive development.

Figure 1 SHAPE weekly training model (see online version for colours)

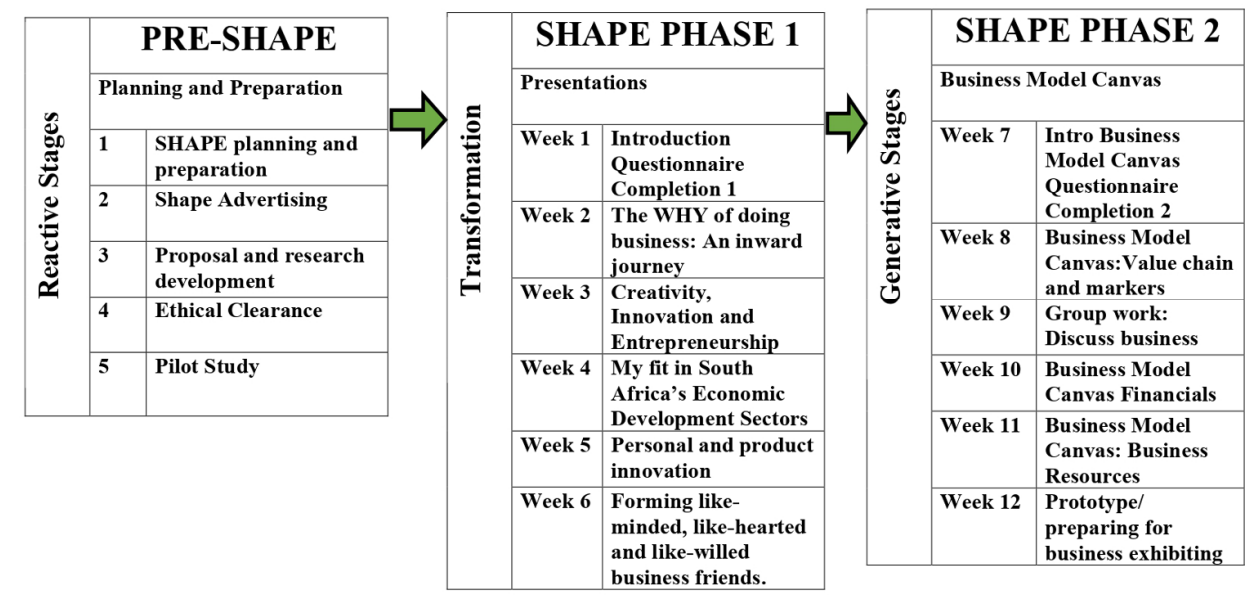

Figure 1 presents the SHAPE training weekly activities reflecting how learners co-initiated and met with like-minded, like-hearted and like-willed business friends applying SALAR to deconstruct their perceptions about entrepreneurship action and sustainability. This approach is also seen as a paradigm shift from classroom learning that cannot translate into entrepreneurial intention and action to SALAR (Laviolette et al., 2012). Figure 1 reveals weekly activities and progressive development stages where the idea was discussed and taught and innovation and creativity were developed to activate intention. This invariably produces a skilled entrepreneurship graduate and facilitates the creation of employment opportunities that will reduce the graduate and youth unemployment rate in the country and positively affect the economy. The employment of systems in training might help in determining the relationships that exist within the ESE constructs to harness participants' potential in terms of identifying opportunities and 
acting on their intentions. This research was limited to the development of entrepreneurship participants (students and youth) in a university applying SALAR, focusing on honours students, postgraduates and other volunteers.

\section{Analysis and discussion}

The data were analysed using the Statistical Package for the Social Sciences (SPSS V.26). Descriptive statistics were used for sample characterisation while correlation coefficient analyses were employed to test the relationships between the self-efficacy constructs. The analysis investigated entrepreneurial development through ESE as a driver of students' entrepreneurial intentions and action with relevant data obtained and analysed to validate the research hypotheses and achieve the study's objectives.

\subsection{Demographic profile of the participants}

A total of 230 participants, third-year entrepreneurial students in the School of Management, IT and Governance volunteered to participate in the study, 60 of which were consistent during the training program. Of the 60 consistent participants, 56 were students $(93.3 \%)$ and $4(6.7 \%)$ represented sponsors of the SHAPE project, $36(60 \%)$ of the participants were female and $24(40 \%)$ were male. This was consistent with the gender composition of the student population in South African universities at the time of the study (Council of Higher Education, 2017). Thirty-three participants (63\%) were black indigents (this indicated the composition of South African citizens, where the four race groups were referred to as black, coloured, white and Indian, besides black people from other countries), nine (15\%) selected the category of foreign 'black' participant, two $(3.3 \%)$ were coloured and sixteen $(26.7 \%)$ were Indian. This indicates that numerous black South Africans are interested in developing entrepreneurial skills. Thirty-eight $(63.3 \%)$ of the participants were degree holders, sixteen $(26.7 \%)$ had a matric certificate and six had post-graduate qualifications. These statistics revealed that entrepreneurship is an attractive option for people with various educational qualifications and that their previous degrees did not guarantee employment, resulting in participation in the project to develop their entrepreneurship potential and skills. Fifty-three participants $(88.3 \%)$ lived in the eThekwini District of KwaZulu-Natal, the business hub of the province, which inspired a desire to participate and develop entrepreneurial skills. The low number of consistent participants was found to be linked to the clash of lecture and training hours and the distances between the various campuses of the institution, which hindered the participants' movement to the training venue. Table 1 hereunder presents the relationships between the observed variables.

Table 1 presents a significant contribution to theory and explains the impact of the association between the fourconstructs of ESE and the social technology that was applied (SHAPE), Theory U and the effects thereof on the participants' progressive development. This is consistent with Murray and O'Fallon's (2020) findings that there is a significant relationship between action learning and learners' progressive entrepreneurship development, as indicated in Table 1. 
Table 1 Pearson's correlation coefficient

\begin{tabular}{|c|c|c|c|c|c|c|c|c|c|}
\hline \multirow[b]{2}{*}{ CONSTRUCTS } & \multicolumn{3}{|c|}{ ROUND 1} & \multicolumn{3}{|c|}{ ROUND 2} & \multicolumn{3}{|c|}{ ROUND 3} \\
\hline & 1 & 2 & 3 & & & & & & \\
\hline OI_SE & - & & & - & & & - & & \\
\hline REL_SE & $0.720 * *$ & - & & $0.642 * *$ & - & & $0.751 * *$ & - & \\
\hline MNG_SE & $0.650 * *$ & $0.583 * *$ & - & $0.701 * *$ & $0.834 * *$ & - & $0.796^{* *}$ & $0.901 * *$ & - \\
\hline TOL_SE & $0.530^{* *}$ & $0.428 * *$ & $0.701^{* *}$ & $0.532 * *$ & $0.704 * *$ & $0.817^{* *}$ & $0.737 * *$ & $0.777 * *$ & $0.833 * *$ \\
\hline
\end{tabular}

*Correlation is significant at the 0.05 level (2-tailed) and **Correlation is significant at the 0.001 level (2-tailed).

The Pearson's correlation coefficients in Table 1 indicate the nature of the relationships between the four constructs of ESE. For round one, the correlation coefficients $r=0.720$, $n=59, p<0.001 ; r=0.650, n=58, p<0.001$ and $r=0.530, n=58, p<0.001$ show that there is a positive relationship between opportunity identification self-efficacy and relationship self-efficacy, managerial self-efficacy and tolerance self-efficacy respectively. The correlation coefficients $r=0.583, n=58, p<0.001$ and $r=0.428$, $n=58, p<0.001$ show that there is a positive relationship between relationship selfefficacy and managerial and tolerance self-efficacy. Finally, the correlation co-efficient $r=0.701, n=57, p<0.001$ indicates a positive relationship between managerial selfefficacy and tolerance self-efficacy. The implication of this is that SALAR has a significant effect on the ESE development for entrepreneurial intention building, which was not limited to the participants' intention but also shaped their behaviour.

In round two, the correlation coefficients $r=0.642, n=57, p<0.001 ; r=0.701$, $n=58, p<0.001$ and $r=0.532, n=53, p<0.001$ show that there is a positive relationship between opportunity identification self-efficacy and relationship, managerial and tolerance self-efficacy respectively. The correlation coefficients $r=0.834, n=55$, $p<0.001$ and $r=0.704, n=53, p<0.001$ indicate a positive relationship between relationship self-efficacy and managerial and tolerance self-efficacy. Finally, the correlation coefficient 0.817 indicates that there is a positive relationship between managerial self-efficacy and tolerance self-efficacy.

In round three, the correlation coefficients $r=0.751, n=56, p<0.001 ; r=0.796$, $n=53, p<0.001$ and $r=0.737, n=53, p<0.001$ showed that there is a positive relationship between opportunity identification self-efficacy and relationship, managerial and tolerance self-efficacy respectively. The correlation coefficients $r=0.901, n=56$, $p<0.001$ and $r=0.777, n=54, p<0.001$ illustrate a positive relationship between relationship self-efficacy and managerial and tolerance self-efficacy. Finally, the correlation coefficient $r=0.833, n=54 p<0.001$ showed that there is a positive relationship between managerial self-efficacy and tolerance self-efficacy. The observed $p$-value induced no conventional statistical significance at $p=0.001, \leq 0.05$ (2 tailed). The table indicates progressive development from rounds one to three based on the effect of the SALAR and SHAPE training method and model applied respectively. Table 2 presents the regression analysis for hypothesis 2 indicating the relationship between the entrepreneurship self-efficacy constructs and entrepreneurship intention and action. 
Table 2 Regression analysis for ESE and EI and EA

\begin{tabular}{lcccccccc}
\hline Variables & Rounds & $R$ & $R$ square & $\begin{array}{c}\text { Adjusted } \\
R \text { square }\end{array}$ & $F$ & Beta & $T$ & $P$ \\
\hline Constant & Round 1 & $0.583^{\mathrm{a}}$ & 0.340 & 0.325 & 21.664 & & 11.214 & $0.583^{\mathrm{b}}$ \\
ESE & & & & & & 0.583 & 4.654 & 0.000 \\
Constant & Round 2 & $0.519^{\mathrm{a}}$ & 0.269 & 0.251 & 14.732 & & 9.263 & $0.519^{\mathrm{b}}$ \\
ESE & & & & & & 0.519 & 3.838 & 0.000 \\
Constant & Round 3 & $0.505^{\mathrm{a}}$ & 0.255 & 0.237 & 14.045 & & 7.435 & $0.505^{\mathrm{b}}$ \\
ESE & & & & & & 0.505 & 3.748 & 0.001 \\
\hline
\end{tabular}

Regressions is significant at $0.583^{\mathrm{a}}$ level $\left(2\right.$ tailed) and $\mathrm{p}$. at $0.583^{\mathrm{b}}(<0.001)$ in round 1 ; at $0.519^{\mathrm{a}}$ level $(2$ tailed $)$ and p. $0.519^{\mathrm{b}}(<0.001)$ in round 2 , and at $0.505^{\mathrm{a}}$ level $(2$ tailed $)$ and $\mathrm{p}$. at $0.505^{\mathrm{b}}(<0.001)$ in round 3 .

Table 2 presents a regression model from round 1, where ESE shows an $R$ square of 0.340 and adjusted $R$ square of 0.325 . This indicates that the model (entrepreneurial selfefficacy) predicts $32.5 \%$ of the variations in the participants' intention and action during the training. There is a significant relationship (at $p<0.001$ ) between ESE and action. In round 2, the $R$ square of 0.269 and adjusted $R$ square of 0.251 indicate that the model predicts $25.1 \%$ of the variation in the participants' intention and action during the training and also that there is a significant relationship between the constructs (at $p<0.001$ ). Round 3 shows an $R$ square of 0.255 with an adjusted $R$ square of 0.237 , which indicates that the model predicts $23.7 \%$ of the variation in the participants' intention and action during the training and that there is a significant relationship between the constructs (at $p<0.001)$. The results obtained in the three rounds revealed progressive development from round one to round three of the project in support of the hypothesis that there is a relationship between entrepreneurship self-efficacy constructs and entrepreneurship intention and action development. The standardised Beta and corresponding P-value for $\mathrm{ESE}$ and intention in the three rounds were $\beta=0.583, p<0.001 ; \beta=0.519, p<0.001$ and $\beta=0.505, p<0.001$ respectively.

Given the significance of each round, the results revealed $t$-statistics at $t=4.654$, $p<0.001 ; t=3.838, p<0.001$ and $t=3.748, p<0.001$. This indicates that ESE as a variable positively affects the participants' entrepreneurship momentum to be innovative, creative, launch a business and grow and sustain that business upon graduation. This result addressed the research objective that aimed to determine if there is a significant relationship between entrepreneurial self-efficacy and individual entrepreneurial intention and action. The result of the regression model is consistent with the outcome of the correlation coefficient analysis that was conducted in which it was found that there was a correlation between the ESE and EI of the participants in the training project. On this basis, it was concluded that ESE served as a predictor of the participants' entrepreneurship intention and action. 


\subsection{Findings}

The findings indicated that applying SHAPE social technology and Theory $U$ for the training brought about a positive correlation between the ESE constructs and the participants' progressive development. The empirical study showed that ESE development employing SALAR and the SHAPE training model had a significant progressive effect on the participants to act on their entrepreneurial intention and action. To support this, the measures were repeated and revealed that the mean $(M)=2.24$; Std. Deviation $=0.83 ; M=5.05$, Std. Deviation $=0.845$ and $M=5.52$, Std. Deviation $=0.930$ from rounds one to three respectively. This implies progressive change, development and behavioural change at intervals during the training. The results presented in Tables 1 and 2 indicate that learning took place and the participants were transformed at intervals from having theoretical knowledge to gaining skills and becoming innovative and creative studentpreneurs. The implication is that a combination of different systems (professionals, technology, institutional environment and entrepreneurship enablers) in learning entrepreneurship can influence learners' self-efficacy and decisions to act. This is consistent with the findings of Almeida and Terra (2019) who suggested that an innovative context can influence the development of enterprises through various factors. As a result of thirteen-weeks' of SHAPE training, seventy-three of the overall registered participants, through the entrepreneurship self-efficacy skills learnt in the training, expressed their intention to create ventures immediately after the project. This would sustain their development after their studies to create employment for the increasing population in accordance with the country's SDGs. This is consistent with a similar study conducted by Van der Westhuizen (2016), which found that SALAR informs students' development and venture creation after training. This was significant at $p=0.01 \leq 0.05$ (2 tailed). These findings concur with a similar study undertaken by Nyamuda (2018), who found that the SHAPE social technology was effective in increasing positive responses to ESE as explored through SALAR, indicating the implications of self-volunteering for the developmental training program. This is also consistent with the views of Ho et al. (2018) who claimed that those who underwent entrepreneurship training had significantly higher alertness and efficacy than those who did not go through such training.

The findings also indicated that the SALAR and SHAPE training, in accordance with the aim of the study and the SDGs to focus on addressing unemployment, eradicating poverty and other factors that prevent people from being productive members of society, improved cognitive and motivational mindset outcomes resulting in entrepreneurial intention. This is consistent with the findings of Balica et al. (2016), Olugbola (2017) and Botha (2006) who found that entrepreneurship training is effective in promoting cognitive skills. Research hypothesis 1 was therefore validated and accepted.

The results differed from the findings of Fayomi (2017), who found that a blended teaching and learning approach developed students to prefer employment in an existing organisation rather than starting their own business. It showed that more theoretical and abstract teaching was employed in the majority of African countries rather than action learning and training. It revealed that such a practice significantly influences graduates' choice of working at an existing firm as opposed to entrepreneurial intention. The reasons can be ascribed to different learning methods, among others. Fayomi (2017) evaluated blended teaching methods employed at universities whereas this study involved voluntary entrepreneurship training with self-selected participation and an experienced facilitator of entrepreneurship development. It is proposed that the ability to engage students in self- 
practices could expose learners to creativity and the discovery of new knowledge, which would lead to increased entrepreneurial intention.

This study revealed that the participants were interested in their individual selfdevelopment as illustrated by their participation during their university's primary aim of degree acquisition. This is an indication of an open mind and heart and the will to strive for a new future and for the old self to start disrupting the market through innovation and creativity for individual and collective evolvement. It also indicated the positive effect of the SHAPE training and development project and the application of Theory $U$ in the participants' responses through the median of six and seven (somewhat confident and mostly confident) to the measurements which showed that learning did take place and the participants were transformed. As a result thereof, research hypothesis 2 was validated and accepted.

\section{Recommendations and conclusion}

Based on the findings of this study, it is appropriate to conclude that students' ESE and entrepreneurial intention and action can be harnessed and developed. This was revealed in the employment of an entrepreneurial training intervention for this study via the social transformative learning pedagogical methods of SALAR. It was revealed that the participants were developed and that transformation took place because seventy-three of the participants indicated their intention for venture creation immediately after the training and they were referred to the entrepreneurship enabler (UKZN Inqubate) in the university for mentoring and supervision.

This is consistent with Nyamuda and Van der Westhuizen's (2018) study, which revealed that learning by doing and experiential learning enhanced skills development more than entrepreneurial education only, which is long-term learning and theoretical. This is because action learning applying technology in teaching encourages the generation of ideas and the identification of opportunities, as entrenched in the UNSDGs for education and the sub-goals for technology and innovation development. It also empowers students with business skills and the ability to identify venture gaps and to become more innovative and creative through the learning stages in Theory U. The study also found that the development stages of Theory $U$ could be used to activate entrepreneurial potential among the youth through collective reasoning, which enables them to connect with like-minded, like-hearted and like-willed business enablers that construct the propensity to create ventures after graduation (Fayomi, 2017; Van der Westhuizen, 2018).

This study had several limitations mainly that the sample (students) was from a single university (University of KwaZulu-Natal) in South Africa. It is therefore recommended that future studies be carried out, preferably simultaneously in several universities, perhaps in more than one country, employing qualitative or mixed methods designs to engage academia and professionals in in-depth interviews to extract further information regarding the relevant eco-systems and how they affect entrepreneurship development. The study should also be replicated in other sub-samples of the general population with different characteristics to be able to generalise the study. 


\subsection{Theoretical and practical implications}

Systemic action learning and action research is relevant not only in students' entrepreneurial development but also generally for the training and retraining of entrepreneurs from established firms. It facilitates the co-creation of an entrepreneurial eco-system. This could reduce rising levels of social vices and youth unemployment. Overall, the expansion of this research is recommended to confirm the results obtained with this study. For this reason, prospective researchers can replicate and expand the model proposed in the study. In particular, entrepreneurial training across all university disciplines is recommended to confirm the training potential for youth development.

\section{Acknowledgements}

- This work is based on the research supported in part by the National Research Foundation of South Africa (Grant Number: 122002) and

- $\quad$ The University of KwaZulu-Natal, School of Management, Information Technology andGovernance.

\section{References}

Ajzen, I. (2011) 'The theory of planned behaviour: reactions and reflections', Psychology \& Health, Vol. 26, No. 9, pp.1113-1127, DOI: 10.1080/08870446.2011.613995.

Almeida, M. and Terra, B. (2019) 'Technological strategies and sustainable management for small businesses in the Brazilian innovation context', International Journal of Innovation and Sustainable Development, Vol. 13, No. 1, pp.20-35.

Arawaana, S. (2010) 'Expanding young people's capacity to learn', British Journal of Educational Studies, Vol. 55, No. 2, pp.115-134.

Arenius, P. and Minniti, M. (2005) 'Perceptual variable and nascent entrepreneurship', Small Business Economics, Vol. 24, No. 3, pp.233-247.

Audretsch, D.B. (2007) 'Entrepreneurship capital and economic growth', Oxford Review of Economic Policy, Vol. 23, No. 1, pp.63-78.

Balica, M., Benga, O., David-Crisbasanu, S., Goia, D., Iftode, O. and Caragea, V.M. (2016) Non-Cognitive Skill Development in Adolescents in Romania, UNICEF Romania.

Bandura, A. (1986) Social Foundations of Thought and Action, Prentice-Hall, Englewood Cliffs, NJ.

Barbosa, S.D., Gerhardt, M.W. and Kickul, J.R. (2007) 'The role of cognitive style and risk preference on entrepreneurial self-efficacy and entrepreneurial intentions', Journal of Leadership and Organisational Studies, Vol. 13, No. 4, pp.86-104.

Baronov, D. (2015) Conceptual Foundations of Social Research Methods, Routledge.

Binnui, A. and Cowling, M. (2016) 'A conceptual framework for measuring entrepreneurship and innovation of young hi-technology firms', Journal of Business Review (GBR), Vol. 4, No. 3, DOI: 10.5176/2010-4804_4.3.383.

Bitzer, V. and Bijman, J. (2015) 'From innovation to co-innovation? an exploration of African agrifood chains', British Food Journal, Vol. 117, No. 8, pp.2182-2199.

Botha, M. (2006) Measuring the Effectiveness of the Women Entrepreneurship Programme, as a Training Intervention, on Potential, Start-Up and Established Women Entrepreneurs in South Africa, Doctoral dissertation, University of Pretoria. 
Bowmaker-Falconer, A. and Herrington, M. (2019/2020) Igniting Startups for Economic Growth and Social Change, Global Entrepreneurship Monitor South Africa (GEM SA) 2019/2020 report.

Boyd, N.G. and Vozikis, G.S. (1994) 'The influence of self-efficacy on the development of entrepreneurial intentions and actions', Entrepreneurship Theory and Practice, Vol. 18, No. 4, pp.63-77.

Butz, A.R. and Usher, E.L. (2015) 'Salient sources of early adolescents' self-efficacy in two domains. Contemporary Educational Psychology, Vol. 42, pp.49-61.

Cardon, M.S. and Kirk, C.P. (2015) 'Entrepreneurship passion as mediator of self-efficacy to persistence relationship', Entrepreneurship Theory and Practice, Vol. 39, No. 5, pp.1027-1050.

Ceresia, F. and Mendola, C. (2019) 'Entrepreneurial self-identity, perceived corruption, exogenous and endogenous obstacles as antecedents of entrepreneurial intention in Italy', SocialSciences, Vol. 8, No. 2, p.54.

Chen, C.C., Greene, P.G. and Crick, A. (1998) 'Does entrepreneurial self-efficacy distinguish entrepreneurs from managers?', Journal of Business Venturing, Vol. 13, No. 4, pp.295-316.

Clegorne, N. and Mitchell, R. (2013) 'Student-centered empowerment of teacher-centered practices: an action research project', Networks: An Online Journal for Teacher Research, Vol. 15, No. 1, pp.628-628.

Comaroff, J. and Comaroff, J.L. (2012) 'Theory from the south: or, how Euro-America is evolving towards Africa', Anthropological Forum, Vol. 22, No. 2, pp.113-131.

Council of Higher Education (2017) Vital Stats Public Higher Education 2015, Council of Higher Education, Pretoria.

Dahling, J.J., Melloy, R. and Thompson, M.N. (2013) 'Financial strain and regional unemployment as barriers to job search self-efficacy: a test of social cognitive career theory', J. Couns. Psychol., Vol. 60, pp.210-218.

De Noble, A., Jung, D. and Ehrlich, S. (1999) 'Entrepreneurial self-efficacy: the development of a measure and its relationship to entrepreneurial action', in Reynolds, D., Bygrave, W.D., Manigart, S., Mason, C.M., Meyer, G.D., Sapienze, H.J. and Shaver, K.G. (Eds.): Frontiers of Entrepreneurship Research, P \& R Publication Inc., Waltham, MA

Devonish, D., Alleyne, P., Charlles-Soverall, W., Marshall, Y.A. and Pounder, P. (2010) 'Explaining entrepreneurial intentions in the Caribbean', International Journal of Entrepreneurial Behaviour and Research, Vol. 16, No. 2, pp.149-171.

Dhliwayo, S. (2008) 'Experiential learning in entrepreneurship education', Education + Training, Vol. 50, No. 4, pp.329-340.

Drnovsek, M., Wincent, J. and Cardon, M.S. (2010) 'Entrepreneurial self-efficacy and business start- up: developing a multi-dimensional definition', International Journal of Entrepreneurial Behaviour and Research, Vol. 16, No. 4, pp.329-348.

Fayomi, E.J. (2017) A Conceptual Framework for Teaching and Learning Entrepreneurship in University in South-West Nigeria, Doctoral thesis, University of KwaZulu-Natal.

Fourie, W. (2018) 'Aligning South Africa's National Development Plan with the 2030 Agenda's Sustainable Development Goals: Guidelines from the policy coherence for development movement. Sustainable Development, Vol. 26, No. 6, pp.765-771.

Fritsch, M. (2017) 'The theory of economic development - an inquiry into profits, capital, credit, interest, and the business cycle', Regional Studies, Vol. 51, No. 4, pp.654-655, doi: $10.1080 / 00343404.2017 .1278975$.

Ghoddousi, P., Bahrami, N., Chileshe, N. and Hosseini, M.R. (2014) 'Mapping site-based construction workers' motivation: expectancy theory approach', Construction Economics and Building, Vol. 14, No. 1, pp.60-77.

Gosling, S.D., Vazire, S., Srivastava, S. and John, O.P. (2004) 'Should we trust the web-based studies? A comparative analysis of six preconceptions about internet questionnaires', AmericanPsychologists, Vol. 59, No. 2, pp.93-104. 
Herrington, M. and Kew, P. (2016) Global Entrepreneurship Monitor - South African Report 2015/16: Is South Africa Heading for an Economic Meltdown? Development Unit for New Enterprise, UCT, Cape Town.

Hisrich, R.D. and Peters, M.P. (1998) Entrepreneurship. Boston, MA: Irwin McGaw-Hill.

Ho, M-H., Uy, M.A., Kang, B. and Chan, K-Y. (2018) 'Impact of entrepreneurship training on entrepreneurial efficacy and alertness among adolescent youth', Front. Edu., Vol. 3, p.13, doi: 10.3389/feduc.2018.00013.

Holly, Y. (2012) Youth Unemployment is Being Fuelled by an Education Crisis, https://www. theguardian.com/global-development-professionals-network/2014/aug/20/youth-unemploy ment-interactive-pauline-rose (Accessed 15 August, 2010).

Huang, C. (2016) 'Achievement goals and self-efficacy: a meta-analysis', Educational Research Review, Vol. 19, pp.119-137, Available at https://www.sciencedirect.com/science/article/ pii/S1747938X1630029X (Accessed 22 August, 2019).

Jones, H.S. and Muller, A. (2016) The South African Economy, 1910-90, Springer, New York, USA.

Juma, C. (2015) The New Harvest: Agricultural Innovation in Africa, Oxford University Press, New York, NY.

Kapepa, O. and van Vuuren, J. (2019) 'The importance of tolerance for failure and risk-taking among insurance firms in hyperinflationary Zimbabwe', The Southern African Journal of Entrepreneurship and Small Business Management, Vol. 11, No. 1, pp.1-15.

Kasemsap, K. (2016) 'Advocating entrepreneurship education and knowledge management in global business', Handbook of Research on Entrepreneurship in the Contemporary Knowledge-Based Global Economy, IGI Global, pp.313-339.

Krecar, I.M. and Coric, G. (2013) 'Changes in entrepreneurial self-efficacy since completion of entrepreneurial studies', Procedia-Social and Behavioral Sciences, Vol. 89, pp.74-78.

Kubberød, E. and Pettersen, I.B. (2017) 'Exploring situated ambiguity in students' entrepreneurial learning', Education + Training.

Laviolette, E.M., Lefebvre, M.R. and Brunel, O. (2012) 'The impact of story bound entrepreneurial role models on self-efficacy and entrepreneurial intention', International Journal of Entrepreneurial Behavior and Research, Vol. 18, No. 6, pp.720-742.

Lent, R.W., Ireland G.W., Penn, L.T., Morris, T.R. and Sappington, R. (2017) 'Sources of selfefficacy and outcome expectations for career exploration and decision-making: a test of the social cognitive model of career self-management', Journal of Vocational Behaviour, Vol. 99, pp.107-117.

Liñán, F. (2005) 'Development and validation of an entrepreneurial intention questionnaire (EIQ)', 15th Internationalizing Entrepreneurship Education and Training Conference, pp.1-14.

Littlewood, D. and Holt, D. (2015) 'Social entrepreneurship in South Africa: exploring the influence of environment', Business and Society, 0007650315613293.

Mamabolo, M.A., Kerrin, M. and Kele, T. (2017) 'Entrepreneurship management skills requirements in an emerging economy: a South African outlook', The South African Journal of Entrepreneurship and Small Business and Management, Vol. 9, No. 1, pp.2071-3185.

Marais, H. (2013) South Africa Pushed to the limit: The Political Economy Change, UCT Press, Claremont, South Africa.

Matchaba-Hove, T.M. and Goliath, J.E. (2016) 'The entrepreneurial orientation and business performance relationship: a study of young adult-owned small businesses', Proceedings of the 28th Annual Conference of the Southern African Institute of Management Scientists, Pretoria, South Africa.

Meyer, N. and Synodinos, C. (2019) 'Entrepreneurial skills, characteristics and intentions amongst unemployed individuals in the vaal-triangle region of South Africa', Journal of Contemporary Management, Vol. 16, No. 2, pp.1-22. 
Miao, C., Qian, S. and Ma, D. (2016) 'The relationship between entrepreneurial self-efficacy and firm performance: a meta-analysis of main and moderator effects', Journal of Small Business Management, Available:https://onlinelibrary.willey.com/doi/10.1111/jsbm.12240/pdf

Moalusi, K.P. (2016) Perspectives on Trust in Business Alliances in the Black Economic Empowerment Context: AQ Methodological Approach, Doctoral dissertation, University of South Africa.

Morris, J.E. and Lummis, G.W. (2014) 'Investigating the personal experiences and self-efficacy of western Australian primary pre-service teachers in the visual arts', Australian Art Education, Vol. 36, No. 1, p.26.

Morselli, D. (2019) The Change Laboratory for Teacher Training in Entrepreneurship Education: A New Skills Agenda for Europe, Springer Nature p.143.

Mueller, S.L. and Goic, S. (2003) 'East-west differences in entrepreneurial self-efficacy: implications for entrepreneurship education in transition economies', International Journal of Entrepreneurship Education, Vol. 1, No. 4, pp.613-632.

Murray, T. and O'Fallon, T. (2020) 'A summary of research on and with the STAGES developmental model', Integral Review, Vol. 16, No. 1.

Mutanda, M., Lekhanya, L.M. and Moyo, S. (2018) 'The role of international academic professionals in the development of entrepreneurial universities in South Africa: government funded universities perspective', Journal of Economics and Behavioural Studies, Vol. 10, No. 5, pp.284-296.

National Planning Commission (2013) National Development Plan Vision 2030, National Planning Commission, South Africa.

National Youth Enterprise Strategy (2010) Increasing Business Opportunities for Young Women and Men, National Youth Commission South African Youth Fund, Youth Entrepreneurship Campaign 2010, An annex to integrated small business strategy.

Ndayi, N. (2014) Poor Education, Unemployment Threatening National Security. Retrieved on 10 August, 2020, http://www.iol.co.za/opinion/poor-education-unemployment-threateningnational-security-1749133

Ndou, V., Secundo, G., Schiuma, G. and Passiante, G. (2018) 'Insights for shaping entrepreneurship education: evidence from the European entrepreneurship centers', Sustainability, Vol. 10, No. 11, p.4323.

Nowiński, W., Haddoud, M.Y., Lančarič, D., Egerová, D. and Czeglédi, C. (2019) 'The impactof entrepreneurship education, entrepreneurial self-efficacy and gender on entrepreneurial intentions of university students in the visegrad countries', Studies in Higher Education, Vol. 44, No. 2,p361-379.

Nunes, L.B. (2016) 'Schumpeter's Entrepreneurs in the 20th Century: the Tucker Automobile', Technological Forecasting and Social Change, 102., pp.14-20.

Nyamuda, J. (2018) Developing Entrepreneurial Self-Efficacy: A Transformative Learning Theory Approach, PhD Thesis, University of KwaZulu-Natal, Durban. South Africa.

Nyamuda, J. (2018) Developing Entrepreneurial Self-Efficacy: A Transformative Learning Theory Approach, PhD Thesis, University of KwaZulu-Natal, Durban, South Africa.

Nyamunda, J. and van der Westhuizen, T. (2018) 'Youth unemployment: the role of transformative learning in making the youth explore entrepreneurship', Journal of Contemporary Management, Vol. 15, No. 1, pp.314-343.

Olokundun, M.A., Ibidunni, A.S., Peter, F., Amaihian, A.B., Moses, C.L. and Iyiola, O.O. (2017) 'Experiential pedagogy and shared vision: a focus on identification of business opportunities by Nigerian university students', Journal of Entrepreneurship Education, Vol. 20, No. 2, pp.1-12.

Olugbola, S.A. (2017) 'Exploring entrepreneurial readiness of youth and startup success components: entrepreneurship training as a moderator', Journal of Innovation and Knowledge, Vol.2, No. 3, pp.155-171. 
Oseifuah, E.K. (2010) 'Financial literacy and youth entrepreneurship in South Africa', African Journal of Economic and Management Studies, Vol. 1, No. 2, pp.164-182.

Pihie, Z.A.L. and Bagheri, A. (2010) 'Entrepreneurial attitude and entrepreneurial efficacy of technical secondary school students', Journal of Vocational Education and Training, Vol. 62, No. 3, pp.351-366.

Piperopoulos, P. and Dimov, D. (2015) 'Burst bubbles or build steam? Entrepreneurshipeducation, entrepreneurial self-efficacy, and entrepreneurial intentions', Journal of Small Business Management, Vol. 53, No. 4, pp.970-985.

Purvis, R.L., Zagenczyk, T.J. and McCray, G.E. (2015) 'What's in it for me? Using expectancy theory and climate to explain stakeholder participation, its direction and intensity. InternationalJournal of Project Management, Vol. 33, No. 1, pp.3-14.

Sachs, J.D., Schmidt-Traub, G., Mazzucato, M., Messner, D., Nakicenovic, N. and Rockstrom, J. (2019) 'Six transformations to achieve the sustainable development goals', Nature Sustainability, Vol. 2, No. 29, pp.805-814.

Schachtebeck, C. (2018) Individual-Level Intrapreneurial Orientation and Organisational Growth in Small and Medium Enterprises, Doctoral dissertation, University of Johannesburg.

Scharmer, C.O. (2007) 'Theory U: leading from the emerging future', A Social Technology of Freedom (Working Title).

Scharmer, C.O. and Kaufer, K. (2013) Leading from the Emerging Future: From Ego-System to Eco-System Economies, Berrett-Koehler Publishers, San Francisco.

Schweikert, S., Messen, J.O. and Wolf, P. (2013) 'Applying theory U: the case of the creativeliving lab', in Gunnlaugson, O., Baron, C. and Cayer, M. (Eds.): Perspectives on Theory U: Insight From the Field, Business Science Reference, Hershey, PA, USA.

Sekaran, U. and Bougie, R. (2016) Research Methods for Business: A Skill Building Approach, John Wiley \& Sons, Chichester, West Sussex, UK.

Shane, S. and Venkataraman, S. (2000) 'The promise of entrepreneurship as a field of research', Academy of Management Review, Vol. 251, No. 1, pp.217-226.

Shay, D. and Wood, E. (2004) Pilot Impact Evaluation of the Business VENTURE Programme on the Entrepreneurial Attitudes of School Learners - Final Report, UCT Centre for Innovation and Entrepreneurship, Cape Town.

Sisk, T. (2017) Democratization in South Africa: The Elusive Social Contract (Vol. 4838), Princeton University Press, Princeton, New Jersey.

Steenkamp, A.G. (2013) An Assessment of the Impact of Entrepreneurship Training on the Youth in South Africa, PhD Thesis, North-West University Potchefstroom. South Africa.

Strachan, G. (2018) 'Can education for sustainable development change entrepreneurship education to deliver a sustainable future?', Discourse and Communication for Sustainable Education, Vol. 9, No. 1, pp.36-49.

Tfwala, C.H. (2018) The Perceived Impact of Youth Entrepreneurship Development Programmes on Entrepreneurial Aspirations of the Youth in Swaziland, Doctoral dissertation.

The Rockefeller Foundation (2020) Digital Jobs in Africa: Catalysing Inclusive Opportunities for Youth, Available: Catalyzing-Inclusive-Opportunities-For-Youth. pdf (rockefellerfoundation. org) (Accessed 28 February, 2021).

Thompson, E.R. (2009) 'Individual entrepreneurial intent: construct clarification and development of an internationally reliable metric', Entrepreneurship Theory and Practice, Vol. 33, No. 3, pp.669-694.

Tian, B., Zhang, J. and Atinc, G. (2016) An exploratory study on antecedents and dimensions of international entrepreneurial self-efficacy of Chinese new ventures', Proceedings of the United StatesAssociation for Small and entrepreneurship. Conference (P. BS1), United States Association for Small Business and Entrepreneurship, https://search.proquest.com/ openview/baa24a1118158194ca29146dee6fe2ce/1?pg-0risite=gscholar \& cbl=38818 
Tsai, K.H., Chang, H.C. and Peng, C.Y. (2016) 'Extending the link between entrepreneurial selfefficacy and intention: a moderated mediation model', International Entrepreneurship and Management Journal, Vol. 12, No. 2, pp.445-463.Available:https://link.springer.com/article/ 10.1007/s11365-014-0351-2 (Accessed 22 August,2019).

Van der Westhuizen, T. (2016) Developing Individual Entrepreneurial Orientation: A Systemic Approach Through the Lens of Theory $U, \mathrm{PhD}$ thesis, University of KwaZulu-Natal, Durban. South Africa.

Van der Westhuizen, T. (2017) 'Theory U and individual entrepreneurial orientation indeveloping youth entrepreneurship in South Africa', Journal of Contemporary Management, Vol. 14, No. 1, pp.531-553.

Van der Westhuizen, T. (2018) 'Open heart, open mind and open will in transformative individual entrepreneurial orientation pedagogies', 6th International Conference on Innovation and Entrepreneurship: ICIE. 2018, Academic Conferences and Publishing Limited, p.443.

Van der Westhuizen, T. and Goyayi, M.J. (2020) 'The influence of technology on entrepreneurial self-efficacy development for online business start-up in developing nations', The International Journal of Entrepreneurship and Innovation, Vol. 21, No. 3, pp.168-177.

Van der Westhuizen, T. (2021) 'Applying theory U through SHAPE to develop student's individual entrepreneurial orientation in a university eco-system', in Gunnlaugson, O. and Brendel, W. (Eds.): Advances in Presencing Volume III: Collective Approaches in Theory U, Trifoss Business Press, pp.395-435.

Villa-Vicencio, C. (2015) 'Understanding a flawed miracle', The African Renaissance and the Afro-Arab Spring: A Season of Rebirth?, p.31.

Williams, D.M. and Rhodes, R.E. (2016) 'The confounded self-efficacy construct: conceptual analysis and recommendations for future research', Health Psychology Review, Vol. 10, No. 2, pp.113-128, https://www.tandfonline.com/doi/abs/10.1080/17437199.20114.941998 (Accessed 4 October, 2019).

Wood, R. and Bandura, A. (1989) 'Social cognitive theory of organisational management', TheAcademy of Management Review, Vol. 14, No. 3, pp.361-384.

Zhao, H., Seibert, S.E. and Hills, G.E. (2005) 'The mediating role of self-efficacy in the development of entrepreneurial intentions', Journal of Applied Psychology, Vol. 90, No. 6, pp.1265-1272.

\section{Bibliography}

Bandura, A. (1997) 'Self-efficacy: towards a unifying theory of behavioural change', Psychological Review, Vol. 84, No. 2, pp.91-125.

Caprara, G., Vecchione, M., Barbaranelli, C. and Alessandri, G. (2013) 'Emotional stability and affective self-regulatory efficacy beliefs: proofs of integration between trait theory and social cognitive theory', European Journal of Personality, Vol. 27, No. 2, pp.145-154.

McGee, J.E., Peterson, M., Mueller, S.L. and Sequeira, J.M. (2009) 'Entrepreneurial self-efficacy: refining the measure', Entrepreneurship Theory and Practice, Vol. 33, No. 4, pp.965-988.

Spaull, N. (2013) 'Poverty and privilege: primary school inequality in South Africa', International Journal of Educational Development, Vol. 33, No. 5, pp.436-447.

Stats, S.A. (2019) Vulnerability of Youth in South Africa Labour Market. [Online] Available http://www.statssa.gov.za (Accessed 12 December, 2020).

Tshikwatamba, M. (2019) Business Incubation in South Africa, EDHE Lekgotla 2019. 